\author{
Monika Janas, Alicja Zawadzka \\ Faculty of Process and Environmental Engineering, Lodz University of Technology, \\ 90-924 Lodz, Wolczanska 213 \\ monika.janas@edu.p.lodz.pl
}

\title{
NEUTRALIZATION OF POULTRY WASTE BY THERMOHYDROLYSIS IN NEAR-CRITICAL WATER
}

\begin{abstract}
The main problem occurring during poultry and animal production is the management of waste generated in slaughterhouses and poultry processing plants. These wastes, due to the bacteriological threat and the difficulty in storage, adversely affect all elements of the environment and thus require quick neutralization. The prospective method of liquidation of this type of waste is thermohydrolysis in near-critical water.

The aim of the work was to examine the decomposition of poultry waste, i.e. waste blood, soft tissues, chicken heads, feathers, subjected to the process of thermohydrolysis in near-critical water. The decomposition process was carried out at a pressure of $10 \mathrm{MPa}$ in the temperature range of $120^{\circ} \mathrm{C}-250^{\circ} \mathrm{C}$ and with a variable residence time in the reactor.

Detailed analysis of the results allowed us to state that the longer the residence time in the reactor, the higher the content of soluble organic compounds in the liquid phase. The beneficial effect of applying the thermohydrolysis process on the increased reduction of organic substances present in the investigated wastes was also demonstrated.
\end{abstract}

\section{Keywords}

animal waste, thermohydrolysis, near-critical water, neutralisation

\section{Introduction}

The process of food production, using various types of raw materials and technologies, is a source of waste, sewage disposal to waters and/or soil, as well as the emission of dust and gases into the atmosphere. The waste generated during meat processing is particularly troublesome, which results from its physical and chemical properties. The main pollutant arising in slaughterhouses and meat processing plants is sewage which contains fats, tissue remains and blood, as well as meat and bone waste. Waste utilization is very complicated due to its biological instability, high water content, constant oxidative stability and sanitary hazard [1-3].

In the past, various types of bone meal obtained from the processing of animal waste constituted an important source of valuable protein in the nutrition of farm animals. The outbreak of bovine spongiform encephalopathy (BSE) and African swine fever (AFR) has resulted in a reduction in the use of these meals in livestock nutrition. In 1988, the UK introduced the first restriction on the use of meat-and-bone meal derived from ruminants in cattle feed. In 1994, restrictions on the feeding of cattle, sheep and goats with meal derived from the processing of mammalian tissue were already in force in all European Union countries. In 2001, a ban was imposed on the use of animal meal and other defined forms of processed animal protein in the nutrition of farmed animals intended for food production. Due to the risk associated with the spread of BSE and AFR diseases and the probable impact of infected meat on humans, the utilization of post-slaughter waste has been subject to severe formal restrictions [1, 4-6].

The current Regulation of the European Parliament and of the Council of 21 October 2009 (WE) no. 1069/2009 laying down health rules as regards animal by-products not intended for human consumption, indicates thermal treatment as the only effective method to eliminate BSE and AFR from the food chain [7]."

One of the methods of thermal treatment of the waste of animal origin is thermohydrolysis in near-critical water. Water in the sub- and supercritical state is an agent that enables the thermal treatment of animal waste. In supercritical water, during the thermohydrolysis process, pathogenic bacteria are neutralized while organic matter is decomposed into compounds of lower molecular weight. The result is a microbe-free mixture consisting of simple organic compounds that pose fewer problems in the further neutralization process. The 
aim of this work is to investigate the process of thermohydrolysis of animal connective tissue as a waste in near-critical water.

\section{Thermohydrolysis in near-critical water}

Water in the sub- and supercritical state, due to its features, is a very attractive reaction medium. Its high diffusivity and heat capacity guarantee fast mass and heat transfer. The ability to control polarity and solvation capacity as well as non-toxicity and widespread availability of the medium enhance the wide use of near-critical water $[9-11,13]$.

At present, around the world, water in near-critical conditions is mainly used in power engineering, geochemistry, chemical synthesis and in innovative technologies for the neutralization or removal of toxic pollutants. A particularly promising solution is the process of supercritical water thermohydrolysis (SCWT). This method consists of the decomposition of organic compounds, using the properties of water after exceeding its critical point $\left(\mathrm{Tcr}=374^{\circ} \mathrm{C}, \mathrm{pcr}=22.1 \mathrm{MPa}\right)$. It is carried out in the liquid phase, thanks to which the decomposition of high molecular organic compounds occurs more effectively and water molecules are incorporated into the structure of these compounds. A characteristic feature of SCWT is an anaerobic reaction environment which guarantees that there are no problems associated with the corrosion of materials from which the apparatus is built. In addition, the products of thermohydrolysis show a significantly milder action on the apparatus walls than the products of supercritical water oxidation $[8-10,13,14]$.

The main direction of research in the field of supercritical water thermohydrolysis is to explain the reaction and identify compounds formed in this process. In the existing literature on the subject, there is a number of publications devoted to the hydrothermal processes of various groups of organic compounds that are highly toxic or are hardly biodegradable [15-17].

Research on the distribution of many groups of organic compounds was conducted by Martino and Savage [18]. At $460^{\circ} \mathrm{C}$ and $25 \mathrm{MPa}$, they investigated the decomposition of cresols, nitrophenols and benzenediols. Efforts to increase the SCWT efficiency with a simultaneous temperature and pressure reduction contributed to the intensification of studies carried out with the use of catalysts. Thermohydrolysis of chemical substances in supercritical water using catalysts was carried out, among others, by Antal et al. [19], Krammer et al. [20], Penniger et al. [21], Wu et al. [22] and Martin et al. [23]. The catalysts used were mainly inorganic compounds, i.e. sodium chloride, calcium chloride, ferric chloride, sulfuric acid and nitric acid. Many publications on hightemperature hydrolysis were also devoted to carbohydrates, in particular glucose which is relatively easily decomposed even at low temperatures [22, 24]. Martinez et al. [25] investigated the hydrothermal decomposition of cellulose under supercritical water conditions. Researchers also became interested in the possibility of using SCWT to neutralize waste [26-29]. Particular attention was paid to the hydrothermal decomposition of polymers and biopolymers, including polyethylene (PE) $[29,30]$. The authors found that water is a very good solvent for decomposing polycarbonates. They obtained $50 \%$ recovery of phenol from the polymer at subcritical temperatures. Imbierowicz and Chacuk [31] checked the possibility of using thermohydrolysis to liquefy sewage sludge in supercritical water conditions. They carried out hydrothermal decomposition of the activated sludge at a temperature ranging from $423 \mathrm{~K}$ to $523 \mathrm{~K}$ and pressure of 0.2-4.0 $\mathrm{MPa}$, and used the obtained results to formulate a kinetic model describing the process. Research on this issue was also conducted by Bougrier et al. [32] and Laurent et al. [28].

The quoted examples of studies on the process of near-critical water thermohydrolysis constitute just a small fraction of research carried out on this subject. The presented results lead to the conclusion that supercritical water thermohydrolysis is characterized by high application potential and due to its advantages can be used in the future on a large scale.

\section{Aim of the work}

The main problem occurring during intensive poultry production is management of the waste generated in hatching plants, slaughterhouses and poultry processing plants. The aim of this work is to investigate the process of thermohydrolysis of poultry waste in near-critical water. 


\section{Experimental}

The object of thermohydrolysis was waste generated during slaughtering and processing of poultry. These were: waste blood, soft tissues (mainly meat), chicken heads and feathers. The investigated waste immediately before thermohydrolysis was ground three times using a PM200 planetary ball mill and directed to a Nade AD18 laboratory homogenizer which guarantees high homogeneity of mixtures. The analysis showed that the waste consisted of $18 \%$ protein, $2 \%$ fat, $16 \%$ fiber, $9 \%$ ash, $1.2 \%$ calcium, $0.9 \%$ phosphorus and other less significant components.

The $100 \mathrm{~g}$ samples prepared in this way were subjected to thermohydrolysis in a Parr $0.5 \mathrm{dm} 3$ stirred batch high-pressure reactor (Fig. 1). Each type of waste from the poultry industry was analyzed separately. The reactor was made of titanium and equipped with a heating jacket, temperature controller, high-speed stirrer, a system of valves for sampling and a process control unit.

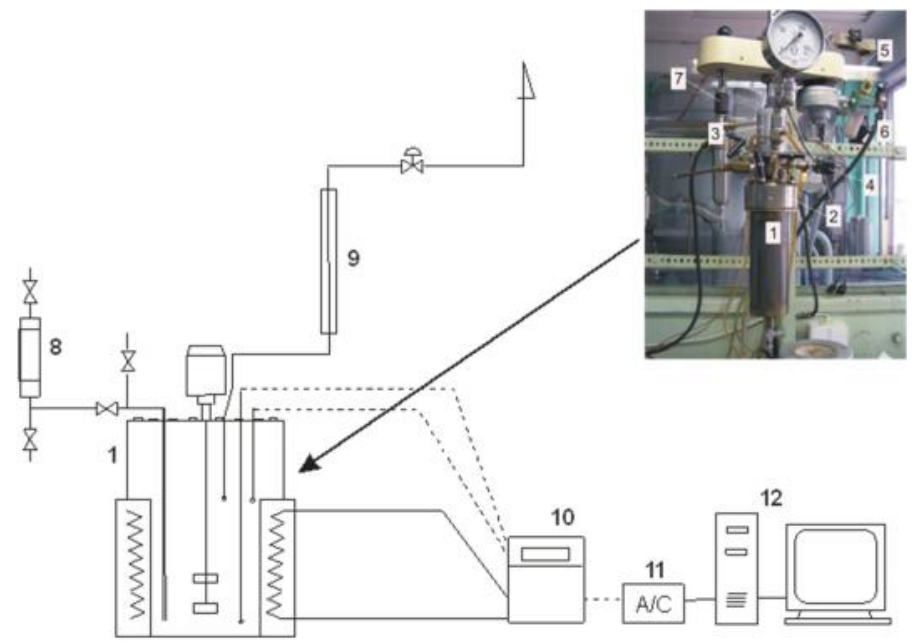

Fig. 1. Schematic of a laboratory setup for testing the process of thermohydrolysis of animal waste in a Parr reactor (1- reactor, 2 - ring, 3 -stirrer, 4 - thermocouple, 5 - turbine, 6 - speed controller, 7 - pivot, 8 - sampling container, 9 - cooler, 10 - controller, 11 - A/C converter, 12 - computer)

Source: Author's

The decomposition process was carried out at a pressure of $10 \mathrm{MPa}$ in the temperature range of $120^{\circ} \mathrm{C}-250^{\circ} \mathrm{C}$ and with residence time in the reactor equal to 30 minutes. The tested samples were analyzed for the content of total organic carbon (TOC) and chemical oxygen demand (COD) in the suspension. TOC was determined by a coulometric method using a Strohlein 702Li/C Coulomat, and the determination of COD was carried out using the dichromate method according to PN-ISO 6060:2006. The method consisted in determining the mass of potassium dichromate in milligrams in terms of oxygen used for oxidation of organic compounds and some inorganic substances present in the analyzed sample.

\section{Results and discussion}

Figure 2 shows results of the COD analysis for samples before and after thermohydrolysis for various fractions of poultry waste. The degree of decomposition of the resulting organic compounds was determined and presented as COD changes in the reaction mass prior to and after the process.

a)

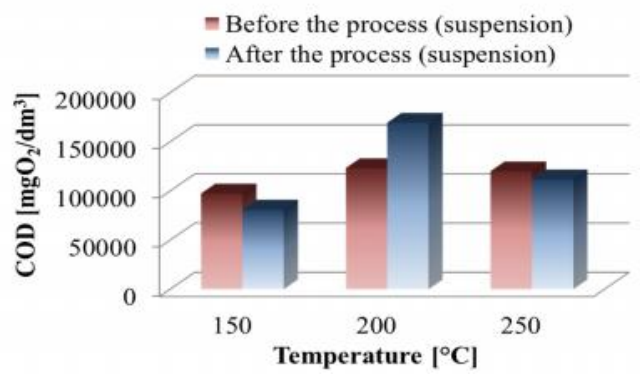

b)

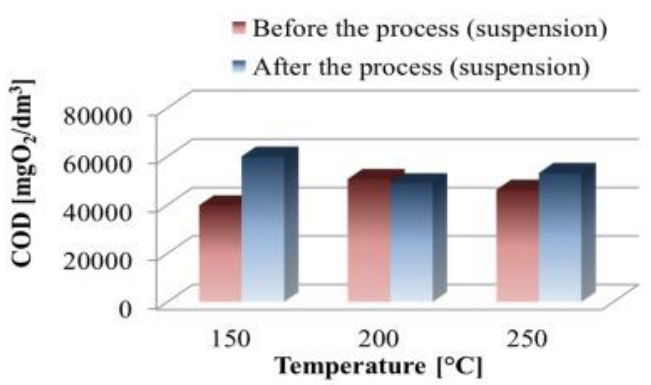


c)

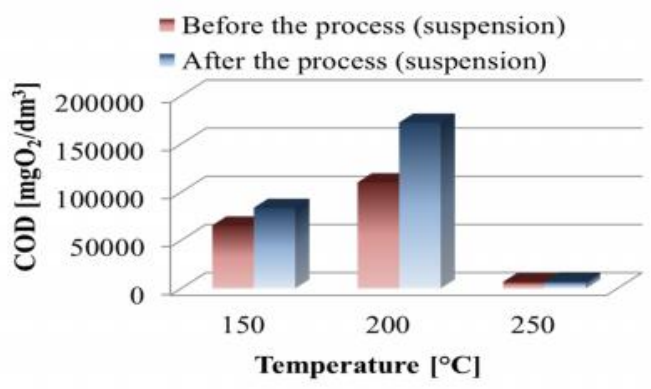

d)

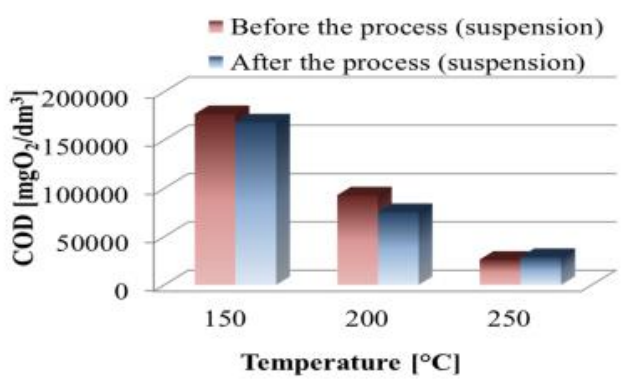

Fig. 2. Changes in COD in the suspension during thermohydrolysis at various temperatures: a) meat, b) feathers, c) chicken heads, d) blood

Source: Author's

When analyzing the presented results, it can be seen that in as many as seven cases the COD of the reaction mass was greater after the process of thermohydrolysis than before it. As a result, satisfactory reproducibility of the test results was not obtained even for the same waste group and the same process conditions.

The TOC indicator was used to further analyze the course of decomposition of the tested waste. The influence of the time of thermohydrolysis on TOC was investigated in the study and the obtained results are presented in Figure 3.

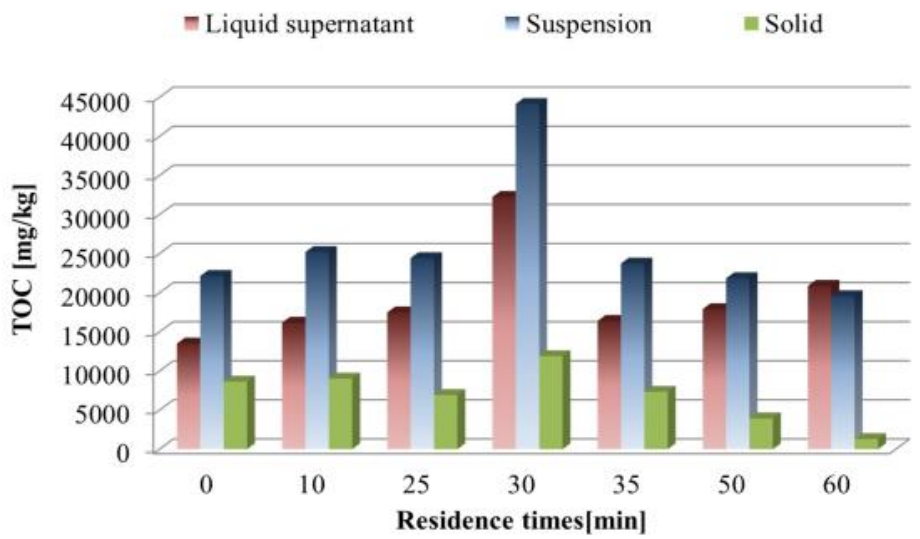

Fig. 3. Changes in TOC concentration $[\mathrm{mg} / \mathrm{kg}]$ in time for the process of meat thermohydrolysis at $200^{\circ} \mathrm{C}$ Source: Author's

A detailed analysis of the results allows us to conclude that the longer the residence time of the mass in the reactor, the higher the content of soluble organic compounds in the liquid phase. This increase is caused by the decomposition of organic compounds in the liquid phase. During the heating of animal waste, biomass dissolution takes place causing an increase in the content of soluble organic compounds in the liquid phase and their decrease in the solid phase. Heating the biomass suspension to $150^{\circ} \mathrm{C}-250^{\circ} \mathrm{C}$ in the reaction system causes that part of organic carbon passes to the liquid phase, while organic carbon present in solid particles obtains a different characteristic than that present in the raw sludge.

\section{Conclusions}

The poultry industry generates large amounts of waste, which in the process of biological processing creates a number of problems. In this connection researchers are looking for more and more efficient methods for neutralization of burdensome production residues.

The paper presents the results of research on the process of near-critical water thermohydrolysis as a method of neutralizing waste from the poultry industry. Both soft and hard parts generated in chicken slaughtering 
process were analyzed. Waste blood coming from the slaughter process, chicken heads and waste feathers as well as muscle tissue in the form of chicken breasts were tested.

As a result of the analyses, it was found that the process of thermohydrolysis of poultry waste depends primarily on the temperature and residence time in the reactor. The longer process time resulted in an increased content of soluble organic compounds in the liquid phase. An important advantage of poultry waste thermohydrolysis is meeting the requirements of legal regulations applicable to the management of waste of animal origin. It is particularly important here to meet the current hygiene requirements for this waste group, which are defined in Regulation (EC) No. 1069/2009 of the European Parliament and of the Council of 21 October 2009 laying down health rules as regards animal by-products not intended for human consumption. This regulation classifies waste of animal origin and defines ways of its neutralization. In the case of the neutralization of material of animal origin with biological methods, it is necessary to pre-pasteurize it at a temperature of at least $70^{\circ} \mathrm{C}$ for low-risk waste or a minimum of $133^{\circ} \mathrm{C}$ for high-risk waste.

In summary, it can be concluded that the process of near-critical thermohydrolysis as a method for neutralizing poultry waste is a particularly promising technological solution. However, it is necessary to continue research on this issue in order to determine the optimal parameters of the process of near-critical thermohydrolysis.

\section{References}

[1] T.L. Oldfield, E. White, N.M. Holden, An environmental analysis of options for utilising wasted food and food residue. J. Environ. Manage. 183 (2016) 826-835

[2] J. Palatsi, M. Vinas, M. Guivernau, B. Fernandez, X. Flotats, Anaerobix digestion of slaughterhouse waste: Main process limitations and microbial community interactions, Bioresource Technology. 102 (2011) 2219-2227

[3] M. Edström, A. Nordberg, L. Thyselius, Anaerobic treatment of animal byproducts from slaughterhouses at laboratory and pilot scale, Appl. Biochem. Biotechnol. 109 (2003) 127-138

[4] P. Klintenberg, M. Jamieson, V. Kinyaga, M. Odlare, Assessing biogas potential of slaugter waste: Can biogas production solve a serious waste problem at abattoirs? Energy Procedia. 61 (2014) 2600-2603

[5] E. Cascarosa, G. Gea, J. Arauzo, Thermochemical processing of meat and bone meal: A review, Renevable and Sustainable Energy Reviews, 16 (1) (2012) 942-957

[6] J. A. Conesa, A. Fullana, R. Font, Thermal decomposition of meat and bone meal, Journal of Analytical and Applied Pyrolysis. 70 (2003) 619-630

[7] Rozporządzenie Parlamentu Europejskiego i Rady z dnia 21 października 2009 r. (WE) nr 1069/2009 określające przepisy sanitarne dotyczące produktów ubocznych pochodzenia zwierzęcego, nieprzeznaczonych do spożycia przez ludzi (Dz.U.UE.L.2009.300.1)

[8] R. Askin, S. Otles, Supercritical fluids, Technologia Alimentaria. 1 (4) (2005) 3-16

[9] M. J. Cocero, Supercritical water processes: Future prospects, The Jurnal of Supercritical Fluids. 134 (2018) $124-132$

[10] A. Martin, M. D. Bermejo, M. J. Cocero, Recent developments of supercritical water oxidation: a patents review, Recent Pat. Chem. Eng. 4 (2011) 219-230

[11] N. Akiya, P. E. Savage, Roles of water for chemical reactions in high-temperature water, Chem. Rev. 102 (2002)

[12] A. Kruse, N. Dahmen, Water - a magic solvent for biomass conversion, The Journal of Supercritical Fluids. 96 (2015) 36-45 
[13] W. He, G. Li, L. Kong, H. Wang, J. Huang, J. Xu, Application of hydrothermal reaction in resource recovery of organic wastes, Resour. Conserv. Recycl. 52 (2008) 691-699

[14] P. Kritzer, Corrosion in high-temperature and supercritical water and aqueous solutions: a review, The Journal of Supercritical Fluids. 29 (2004) $1-29$

[15] L. Zhang, C. Xu, P. Champagne, Overview of recent advances in thermos-chemical conversion of biomass, Energy Convers. Manag. 51 (2010) 969-982

[16] H. A. Ruiz, R. M.Rodriguez-Jasso, B. D. Fernandes, A. A. Vicente, J. A. Teixeira, Hydrothermal processing, as an alternative for upgrading agriculture residues and marine biomass according to the biorefinery concept: $A$ review. Renevable and Sustainable Energy Reviews. 21 (2013) 35-51

[17] S. S. Toor, L. Rosendahl, A. Rudolf, Hydrothermal liquefaction of biomass: a review of subcritical water technologies, Energy. 36 (2011) 2328-2342

[18] Ch. J. Martino, P. E. Savage, Thermal decomposition of substituted phenols in supercritical water. Ind. Eng. Chem. Res 36 (5) (1997) 1385-1390

[19] M. J. Antal, A. Brittain, C. DeAlmeida, S. Ramayya, J. C. Roy, Heterolysis and hemolysis in supercritical water, ACS Szmp. Ser. 329 (1987) 77-86

[20] P. Krammer, H. Vogel, Hydrolysis of esters in subcritical and supercritical water, The Journal of Supercritical Fluids. 16 (2000) 189-206

[21] J. M. L. Penninger, R. J. A. Kersten, H. C. L. Baur, Hydrolysis of diphenylether in supercritical water. Effects of dissolved $\mathrm{NaCl}$, The Journal of Supercritical Fluids. 17 (2000) 215-226

[22] X. Wu, J. Fu, X. Lu, Hydrothermal decomposition of glucose and fructose with inorganic and organic potassium salts, Bioresource Technology. 119 (2012) 48-54

[23] A. Martin, A. Navarrete, M. D. Bermejo, Applications of supercritical technologies to $\mathrm{CO}_{2}$ reduction: Catalyst development and process intensification, The Jurnal of Supercritical Fluids. 134 (2018) 141-149

[24] J. Yin, Z. Cheng, L. Guo, S. Li, H. Jin, Products distribution and influence of nickel catalyst on glucose hydrothermal decomposition, International Journal of Hydrogen Energy. 42 (7) (2017) 4642-4650

[25] C. M. Matinez, D. A. Cantero, M. D. Bermejo, M. J. Cocero, Hydrolysis of cellulose in supercritical; water: reagent concentration as a selectivity factor. 22 (4) (2015) 2231-2243

[26] Y. Matsumura, T. Minowa, B. Potic, S. R. A. Kersten, W. Prins, W. P. M. van Swaaij, B. van de Beld, D. C. Elliott, G. C. Neuenschwander, A. Kruyse, M. J. Antal Jr., Biomass gasification in near- and super-critical water: status and prospects, Biomass Bioenergy. 29 (2005) 269-292

[27] J. Mucha, R. Zarzycki, Analysis of wet oxidation process after initial thermohydrolysis of excess sewage sludge, Water Research. 42 (12) (2008) 3025-3032

[28] J. Laurent, M. Casellas, H. Carrere, C. Dagot, Effects of thermal hydrolysis on activated sludge solubilization, surface properties and heavy metals biosorption, Chemical Engineering Journal. 166 (2011) 841849

[29] ] Z. Fang, Jr. R. L. Smith, H. Inomata, K. Arai, Phase behavior and reaction of polyethylene in supercritical water at pressures up to $2,6 \mathrm{GPa}$ and temperatures up to $670^{\circ} \mathrm{C}$, The Journal of Supercritical Fluids. 16 (2000) 207-216

[30] F. Dubelley, E. Planes, C. Bas, E. Pons, B. Yrieix, L. Flandin, The hydrothermal degradation of PET in laminated multilayer, European Polymer Journal. 87 (2017) 1-13 
[31] M. Imbierowicz, A. Chacuk, Kinetic model of excess activated sludge thermohydrolysis, Water Research. 46 (2012) 5747-5755

[32] C. Bougier, J. P. Delgenus, H. Carrerre, Effects of thermal treatments on five different waste activated sludge samples solubilisation, physical properties and anaerobic digestion, Chemical Engineering Journal. 139 (2008) 236-244 